\title{
PhTAD-Substituted Dihydropyrrole Compounds Regulate Apoptotic Cell Death in
}

\section{MCF-7 Cells}

\author{
Burak YAZGAN ${ }^{1,2^{*}}$, Seda MESCi் $\dot{I}^{3}$, Masuk AKSAHIN ${ }^{2}$, Arif AYAR $^{1,2}$, Melek \\ GÜL 2,4 (D), Tuba YILDIRIM ${ }^{2,5}$ (D)
}
${ }^{1}$ Department of Medical Services and Techniques, Sabuncuoğlu Serefeddin Health Services Vocational School, Amasya University, 05100, Amasya, Turkey
${ }^{2}$ Department of Biotechnology, Institute of Science, Amasya University, 05100, Amasya, Turkey
${ }^{3}$ Scientific Technical Application and Research Center, Hitit University, 19030, Çorum, Turkey
${ }^{4}$ Department of Chemistry, Faculty of Arts and Sciences, Amasya University, 05100, Amasya, Turkey
${ }^{5}$ Department of Biology, Faculty of Arts and Sciences, Amasya University, 05100, Amasya, Turkey

Geliş / Received: 10/03/2021, Kabul / Accepted: 03/06/2021

\begin{abstract}
Breast cancer is the most common type of cancer amongst women. Apoptosis is known as a programmed cell death and this mechanism induces cancer cell death. Dihydropyrrole compounds contain a heterocyclic structure and these molecules have many biological effects including functioning as antioxidants and anticancer molecules.

In this regard, the aim of this research was to investigate how PhTAD-substituted dihydropyrrole compounds affect the expression of apoptotic cell death proteins in the MCF-7 cells. The levels of Bax, Bcl-2, and cleaved caspase-3 proteins in the MCF-7 cells were measured using the ELISA method.

The results revealed that CI, CII, CIII, CV, CVII, CVIII, CXI and CXII increased Bax, while CXIII and CXIV markedly decreased Bax. In addition, compounds CI, CII, CIII, CVII, CVIII, CXI and CXII upregulated Bcl2. Conversely, CIV, and CXIV downregulated Bcl2. Moreover, CIV and CXIV increased the Bax/Bcl2 ratio. However, CVIII and CXIII decreased $\mathrm{Bax} / \mathrm{Bcl} 2$ ratio. In addition, CI, CIV, CIX and CXII treatment increased cleaved caspase-3 in MCF-7 cells compared to the negative control. These findings indicate that the PhTADsubstituted dihydropyrrole derivative molecules induced apoptotic proteins as a potential regulator of cancer cell death.
\end{abstract}

Key Words: Breast Cancer, PhTAD-dihydropyrrole, Apoptosis, Bcl2 family, Caspase 3

PhTAD-Sübstitüe Dihidropirol Bileşikleri MCF-7 Hücrelerinde Apoptotik Hücre Ölümünü Düzenler

\section{$\ddot{\mathbf{O z}}$}

Meme kanseri, kadınlar arasında en sık görülen kanser türüdür. Apoptoz, programlanmış hücre ölümü olarak bilinir ve bu mekanizma kanser hücrelerinin ölümünü indükler. Dihidropirol bileşikleri heterosiklik bir yapı içerir ve bu moleküllerin antioksidan ve antikanser gibi birçok biyolojik etkisi vardır.

Bu noktada, Çalışmamızın amacı, PhTAD türevli dihidropirol bileşiklerinin MCF-7 hücrelerindeki apoptotik hücre ölüm proteinlerinin ifadesini nasıl etkilediğini araştırmaktır.

Bax, Bcl-2 ve kesilmiş kaspaz 3'ün protein miktarları, MCF-7 hücre hattında ELISA yöntemi ile ölçülmüştür. Sonuçlarımız, bileşik (B)I, BII, BIII, BV, BVII, BVIII, BXI ve BXII'nin Bax'ı artırdığını, BXIII ve BXIV'ün

*Corresponding Author: burak_yazgan@yahoo.com 
ise Bax'ı önemli ölçüde azalttığını ortaya koymuştur. Ek olarak, BI, BII, BIII, BVII, BVIII, BXI ve BXII'nin Bcl2'yi yukarı regüle ederken BIV, BXIII ve BXIV'ün Bcl2'yi aşağı regüle ettiği tespit edilmiştir. Ayrıca, BIV ve BXIV'ün Bax / Bcl2 oranını arttırdığı, BVIII ve BXIII'ün ise Bax / Bcl2 oranını düşürdüğü belirlenmiştir. Negatif kontrole kıyasla BI, BIV, BIX ve BXII uygulanan MCF-7 hücrelerinde kesilmiş kaspaz 3 ekspresyonunun arttığı tespit edilmiştir.

Bulgularımız, PhTAD ile türevlendirilmiş dihidropirol moleküllerinin, kanser hücresi ölümünün potansiyel bir düzenleyicisi olarak apoptotik proteinleri indüklediğine işaret etmektedir.

Anahtar Kelimeler: Meme Kanseri, PhTAD-dihidropirol, Apoptoz, Bc12 ailesi, Kaspaz 3

\section{Introduction}

Cancer disease caused by tumors is one of the most significant health problems that human beings are exposed to due both to its high frequency and the risk of death (Ma and $\mathrm{Yu}, 2006$ ). Breast cancer is the most prevalent type of cancer in women (Bray et al., 2018). One in eight women (or about 13 percent) has a risk of developing breast cancer in their lifetime (Howlader et al., 2017).

Apoptosis controlled cell elimination that plays a critical role in embryonic development and adult tissue homeostasis (Zhang et al., 2005; Opferman, 2008; Fuchs and Steller, 2011; Ashkenazi, 2015; AnvariFar et al., 2017). Reducing or eliminating the activation of apoptosis or different cell deaths plays a fundamental role in cancer development (Brown and Attardi, 2005; Jan and Chaudhry, 2019). Apoptosis plays an important and inherent physiological role in eliminating diseased and unnecessary or abnormal cells. Apoptosis can be initiated by a variety of stimuli, including developmental signals, cellular stress, and cell cycle disruption. The development of drugs that target cell death mechanisms in tumors and direct targeting is an important means of cancer treatment (Karna and Yang, 2009). Two separate but interconnected signaling pathways control apoptosis by activating the nuclear intracellular mechanism of death proteases called caspases. The intrinsic apoptotic pathway interacts with caspases through members of the Bcl 2 protein family and mitochondria in response to severe cellular damage or stress. The release of cytochrome $\mathrm{c}$ and apoptosis-activating factors from the mitochondrial membrane is regulated by proteins of the $\mathrm{Bcl} 2$ family. The balance between Bax (Bcl-2-associated X protein) and Bcl2 (B-cell lymphoma 2), which plays a role in the initiation of apoptosis in the intrinsic apoptosis pathway, is critical (Azimian et al., 2018). The extrinsic pathway of apoptotic cell death activates caspases through cell surface death receptors that act on death ligands, especially, through T lymphocytes (Debatin, 2004; Elmore, 2007; Wang and Youle, 2009; Fulda, 2013; Nikoletopoulou et al., 2013; Siddiqui et al., 2015; Kondratskyi et al., 2015; Ashkenazi, 2015; Chen et al., 2018; Jan and Chaudhry, 2019). Apoptosis is initiated in two ways: the death receptor (extrinsic) and the mitochondriadependent (intrinsic) route. The extrinsic pathway begins with the activation of caspase- 8 by ligands that bind to death receptors on the cell surface. The intrinsic pathway causes the cytochrome $\mathrm{C}$ released from mitochondria to from apoptosome in the cytoplasm, resulting in the activation of caspase- 9 and caspase-3, respectively. Caspase- 3 cuts the effector caspases, leading to cell death (Wu et al., 2011; Kominami et al., 2012; Brentnall et al., 2013; Green and Llambi, 2015; Wei et al., 2016; Galluzzi et al., 2018; Elena-Real et al., 2018; Belkacemi et al., 2018). Cancer was first demonstrated to be linked to accelerated and irregular cell proliferation leading to an increase and accumulation of cell mass; it was later found that some cancers are caused by physiological lack of cell death (also known as cellular suicide or apoptosis), rather than an increased rate of cell proliferation (Burz et al., 2009). Currently, the disorder of two well-defined apoptotic signaling pathways, extrinsic/death receptors and the 
intrinsic/mitochondrial pathway, are considered clinical problems that must be overcome in cancer treatment (Debatin, 2004; Fulda, 2013; Belkacemi, 2018).

Dihydropyrroles are a structure commonly found in naturally occurring alkaloids and biologically active substances (Wang et al., 2018). Dihydropyrrole compounds are known for their anticancer activities and suppress cell growth in cancer cells (Tarnavsky et al., 2003). Dihydropyrroles have the capacity to be defined as anticancer agents in cancer cells by causing mitotic arrest, which has an inhibitory effect (Garbaccio, et al., 2006). Dihydropyrrole compounds have inhibitory potential as new therapeutic agents in cancer (Sebastian, 2017).

In this regard, the aim of this research was to investigate how PhTAD-substituted dihydropyrrole compounds affect the expression of apoptotic cell death proteins in MCF7 (human breast adenocarcinoma) cells. The first breast cancer subtype, seen in $70 \%$ of breast cancer patients, is estrogen receptor (ER) and/or progesterone receptor (PR) positive but human epidermal growth factor receptor 2 (HER2) negative. At present many cell lines are used in breast cancer studies. The MCF7 cell line is generally preferred cell since it is positive for ER and PR receptors and negative for HER2 receptor. Because this receptor profile is most frequently observed in patients, MCF 7 cells were chosen for this study. Our findings indicate that the effects of PhTAD-substituted dihydropyrrole derivative molecules induce activity of apoptotic proteins as a potential regulator of cancer cell death. These compounds could be used as a potential molecule for anticancer research.

\section{Materials and methods}

\subsection{Structure of compounds}

PhTAD-substituted dihydropyrrole compounds (C) were synthesized according to our previous studies (Gul et al., 2017; Ayar et al., 2021). Thus, a 1 mmol concentration of dihydropyrrole solution in dichloromethane was added to the $1.1 \mathrm{mmol}$ concentration of PhTAD at $25^{\circ} \mathrm{C}$. After completion reaction $(4-8 \mathrm{~h})$, the crude products were purified by column chromatography. The structures of these compounds are as shown in Figure 1.
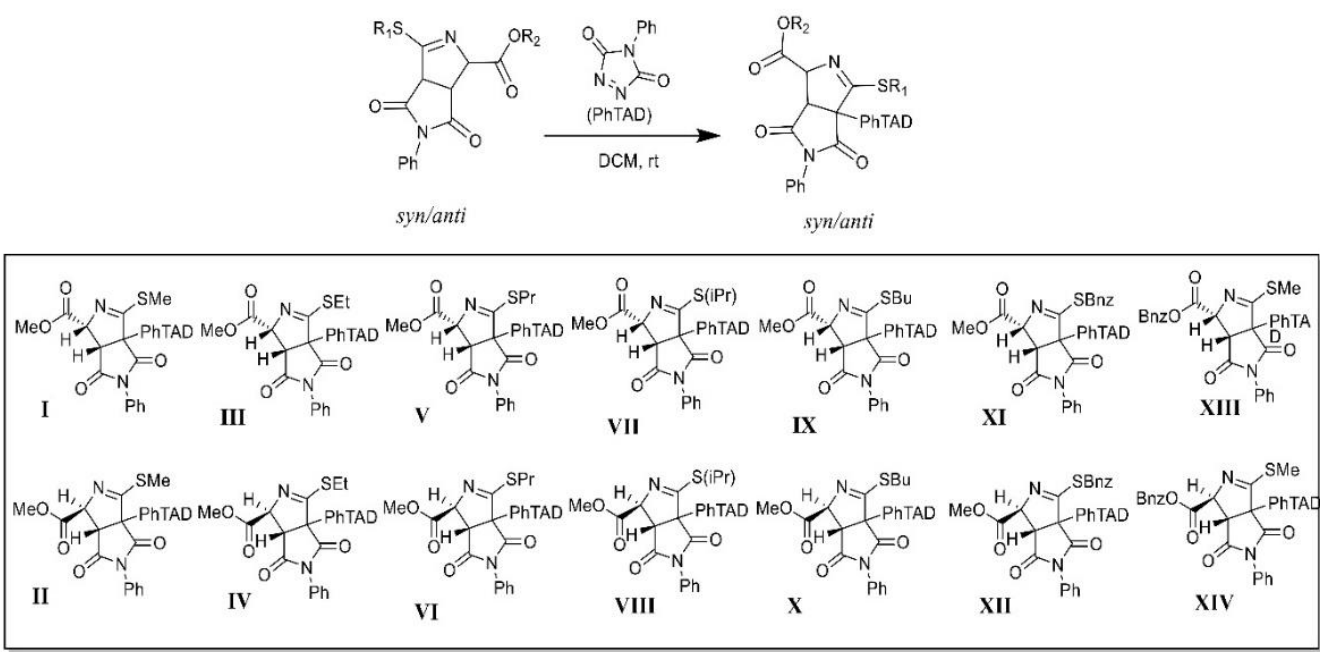

Figure 1. Structure of syn and anti PhTAD-substituted dihydropyrrole compounds. 


\subsection{Cell culture}

In this study, the human breast adenocarcinoma cell line (MCF-7, ATCC ${ }^{\circ}$ HTB22 TM, Manassas, VA, USA) was used for cell culture. MCF-7 cells were cultured an appropriate media containing $25 \mathrm{~g} / 100 \mathrm{~mL}$ sodium bicarbonate (Sigma-Aldrich), $10 \%$ fetal bovine serum (Sigma-Aldrich), RPMI-1640 (Sigma-Aldrich), penicillin/streptomycin (Sigma-Aldrich). All cells were incubated at $37{ }^{\circ} \mathrm{C}$ in a humidified atmosphere of $5 \% \mathrm{CO}_{2}$ in the air. After, the cell populations had grown to $80 \%$ saturation, the cells were washed with phosphate-buffered saline (PBS) and detached from the flasks with $1 \mathrm{X}$ Trypsin-ethylenediaminetetraacetic acid (EDTA). Nearly $2 \times 10^{6}$ cells were seeded per well of the 6 -well culture plate in $3 \mathrm{~mL}$ of growth medium. Cells were incubated at $37{ }^{\circ} \mathrm{C}$ and $5 \% \mathrm{CO}_{2}$ and $90 \%$ humidity for $24 \mathrm{~h}$ until PhTAD-substituted dihydropyrrole compounds were applied.

\subsection{Protein isolation and determination}

PhTAD-substituted dihydropyrrole compounds were appropriately weighed, dissolved in Dimethyl sulfoxide (DMSO) and diluted in the culture medium. The final concentration of DMSO in the treated groups was below $0.1 \%$ and was not cytotoxic. According to the $\mathrm{IC}_{50}$ results obtained in our previous studies appropriate doses were applied on MCF-7, as shown in Table 1 (Ayar et al., 2021).

Table 1. Applied $\mathrm{IC}_{50}$ doses of PhTAD substituted dihydropyrrole compounds.

\begin{tabular}{cc}
\hline Compounds & Dose $(\boldsymbol{\mu M})$ \\
\hline I & 25 \\
\hline II & 25 \\
\hline III & 25 \\
\hline IV & 25 \\
\hline V & 50 \\
\hline VI & 12.5 \\
\hline VII & 12.5 \\
\hline VIII & 12.5 \\
\hline IX & 12.5 \\
\hline X & 12.5 \\
\hline XI & 6.25 \\
\hline XII & 12.5 \\
\hline XIII & 25 \\
\hline XIV & 25 \\
\hline Negative Control & - \\
\hline
\end{tabular}

These compounds were applied to the $2 \times 10^{6}$ cells at the specified doses. After this the cells were incubated at $37{ }^{\circ} \mathrm{C}$ for 24 hours. Then the cells were removed with $1 \mathrm{X}$ trypsin-EDTA and centrifuged at $12500 \mathrm{rpm}$. The supernatant was discarded and $1000 \mu \mathrm{L}$ of cold radioimmunoprecipitation assay (RIPA) buffer (Thermo Fisher Scientific, Cat. No. 89900) was added to the pellet and incubated on ice for $30 \mathrm{~min}$. After incubation, centrifugation was performed for 10 minutes at $12500 \mathrm{rpm}$ and the supernatant was added into a clean tube. Protein concentrations were measured with a bicinchoninic acid (BCA) protein assay kit 
(Pierce BCA Protein Assay Kit, Cat. No. 23225) according to the manufacturer's instructions. The protein concentration in the samples was calculated according to the standard curve in $\mu \mathrm{g} / \mathrm{mL}$. Protein isolates were diluted to $1 / 10$ with RIPA buffer.

\subsection{Detection of apoptosis}

The levels of Bax (MyBioSource, Catalog No: MBS2513810), Bcl2 (Invitrogen, Catalog No: BMS244-3) and cleaved caspase-3 (Invitrogen, Catalog No: KHO1091) in the MCF-7 cells were analyzed using an ELISA kit according to the manufacturer's instructions. Briefly, standards, and controls or diluted protein samples were added in a well plate and incubated at room temperature for $2 \mathrm{~h}$ on a rotating shaker. Then the upper liquid was discarded from the plate. Biotin-conjugate was added to wells and they were incubated at room temperature for 2 $\mathrm{h}$ on a rotating shaker. The upper liquid was then aspirated from the plate. Well plates were washed 5 times with wash buffers. Streptavidin-HRP was added to the well plates and they were incubated at room temperature for $1 \mathrm{~h}$ on a rotating shaker. The upper liquid was aspirated from the plate and the well plates were washed 5 times with wash buffers. TMB Substrate Solution was added, and the well plates were incubated at room temperature for 10 min on a rotating shaker (dark). Stop solution was added to each well. The absorbance of each microwell was measured at $450 \mathrm{~nm}$ using a spectrophotometer (Thermo Multiskan Go). All standards, controls and samples were independently measured in duplicate and the average levels were calculated. Afterwards, the amounts of Bax, Bcl 2 and cleaved caspase- 3 were normalized by proportioning to the total protein amount.

\subsection{Statistics}

Differences between the groups were evaluated statistically by t test using the GraphPad Prism 8.0 software. A p value $<0.05$ was accepted to be statistically significant. Data are presented as mean $\pm \mathrm{SD}$ in the figures.

\section{Results}

\subsection{PhTAD substituted dihydropyrrole compounds alter Bax protein expression in MCF-7 cells}

CI, CII, CIII, CV, CVII, CVIII, CXI, and CXII treatment significantly increased Bax protein expression in the MCF-7 cells approximately 0.5-fold compared to the negative control, as shown in Figure 2. CXIII and CXIV decreased Bax protein levels by $95 \%$ and $70 \%$ respectively. 


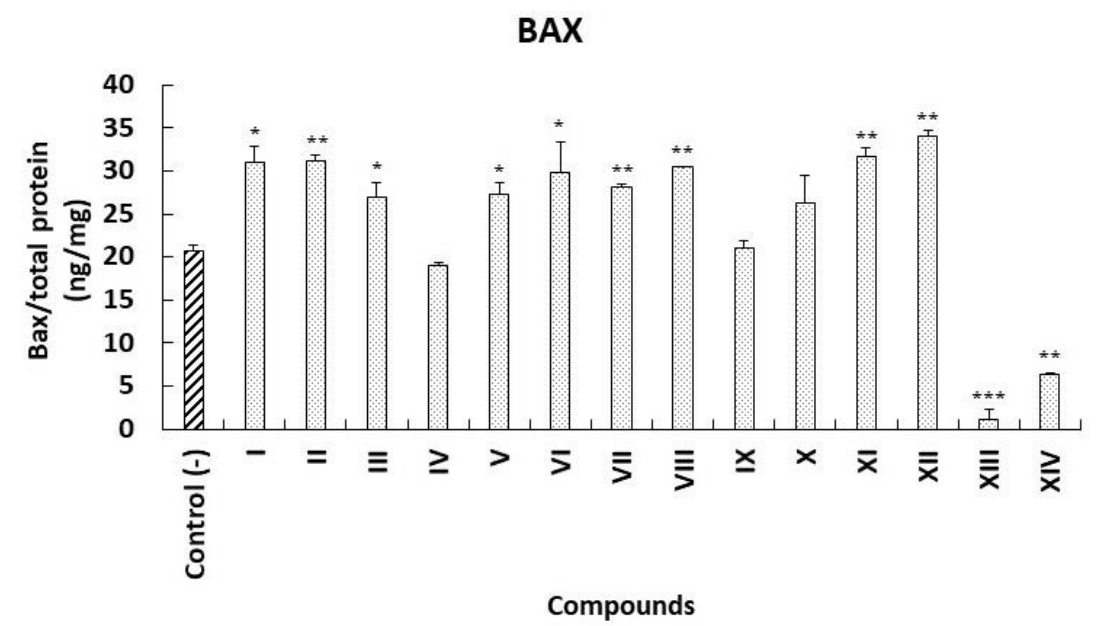

Figure 2. PhTAD-substituted dihydropyrrole compounds alter Bax protein in MCF-7 cells. Data are expressed as mean \pm S.D. $t$ test. ${ }^{* * *} \mathrm{p}<0.001,{ }^{*} \mathrm{p}<0.01$ and $* \mathrm{p}<0.05$ vs negative control. $(n=2)$.

\subsection{Effects of PhTAD substituted dihydropyrrole compounds on Bcl2 protein expression} in MCF-7 cells

$\mathrm{Bcl} 2$ protein expression in the MCF-7 cells was upregulated by CI (1-fold), CII (1-fold), CIII (0.6-fold), CVII (1-fold), CVIII (2-fold), CXI (0.7-fold) and CXII (1-fold) treatment compared to the negative control. However, Bcl2 protein expression was downregulated by CIV (40\%) and CXIV (90\%), as shown in Figure 3.

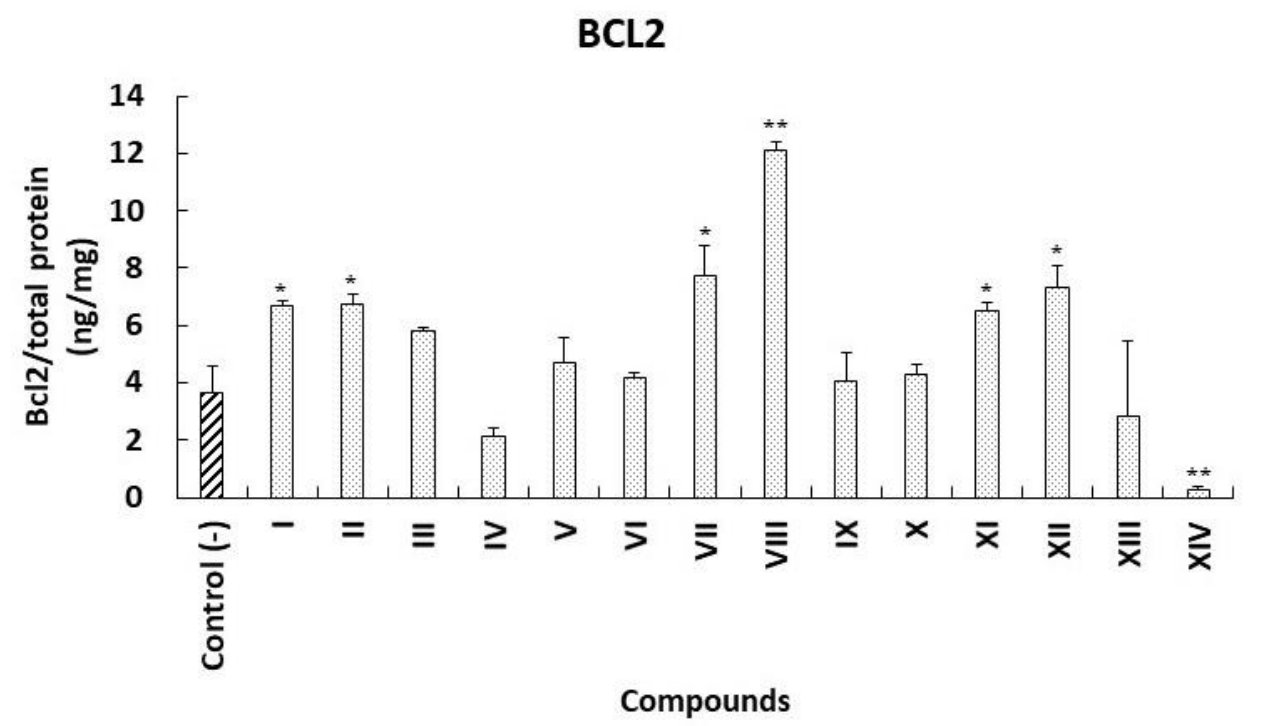

Figure 3. PhTAD-substituted dihydropyrrole compounds modulate $\mathrm{Bcl} 2$ protein in $\mathrm{MCF}-7$ cells. Data are expressed as mean \pm S.D. $t$ test. ${ }^{*} * \mathrm{p}<0.01$ and ${ }^{*} \mathrm{p}<0.05$ vs negative control. $(\mathrm{n}=$ 2). 


\subsection{Effects of PhTAD substituted dihydropyrrole compounds on Bax/Bcl2 ratio in MCF-7 cells}

The Bax/Bcl2 ratio was increased by CIV ( 0.5 -fold) and CXIV ( 3-fold) treatment compared to the negative control in the MCF-7cells. The Bax/Bcl2 ratio was decreased by CVIII $(\sim 55 \%)$ and CXIII $(\sim 90 \%)$ treatment compared to the negative control. Also, this ratio did not change with the application of other compounds (Figure 4 ).

\section{$\mathrm{BAX} / \mathrm{BCL2}$}

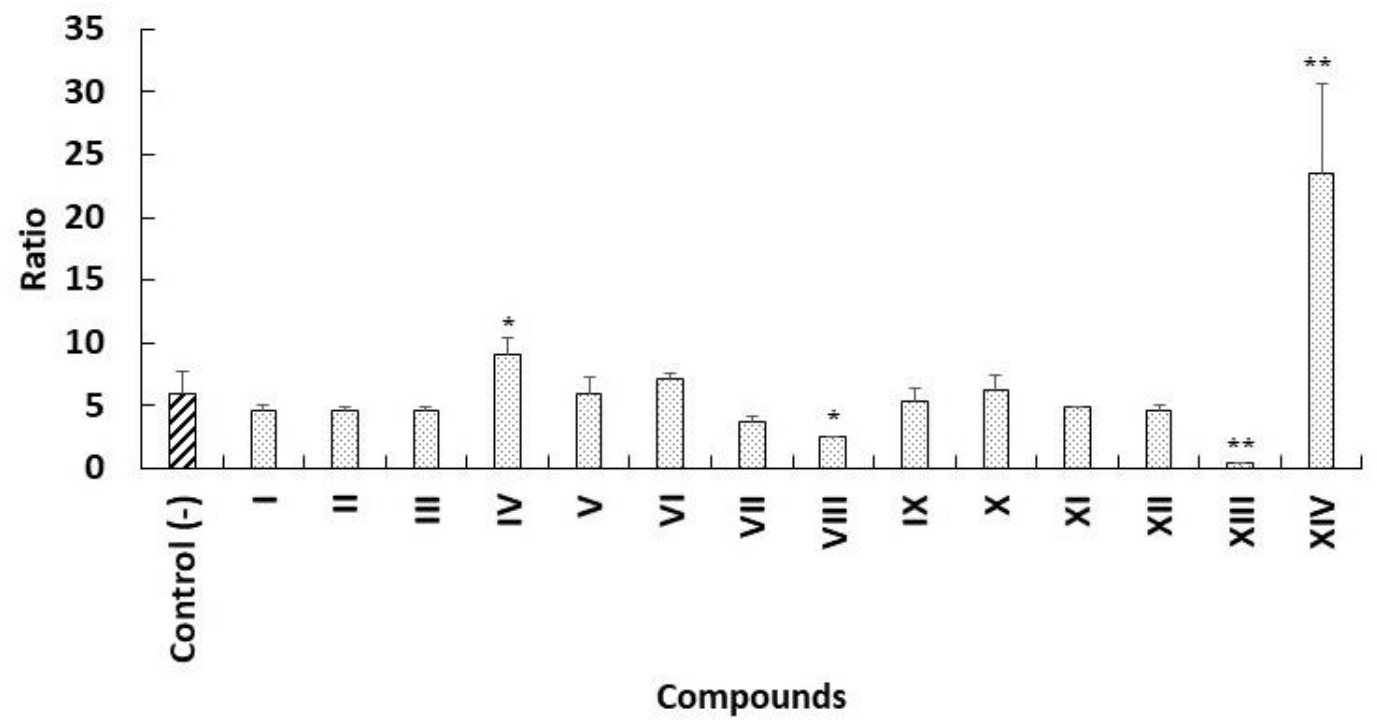

Figure 4. PhTAD-substituted dihydropyrrole compounds alter $\mathrm{Bax} / \mathrm{Bcl} 2$ ratio in $\mathrm{MCF}-7$ cells. Data are expressed as mean \pm S.D. $t$ test. ${ }^{*} \mathrm{p}<0.01$ and ${ }^{*} \mathrm{p}<0.05$ vs negative control. $(\mathrm{n}=2)$.

\subsection{PhTAD substituted dihydropyrrole compounds activate caspase-3 dependent manner apoptosis}

Cleaved caspase-3 protein levels were increased by CI ( $\sim 0.5$-fold), CIV ( 0.3 -fold), CIX (2fold) and CXII (0.5-fold) treatment compared to the negative control in the MCF-7 cells (Figure 5). However, cleaved caspase- 3 protein levels were decreased by CVIII (20\%), CX (20\%), and CXI (15\%) treatment compared to the negative control. 


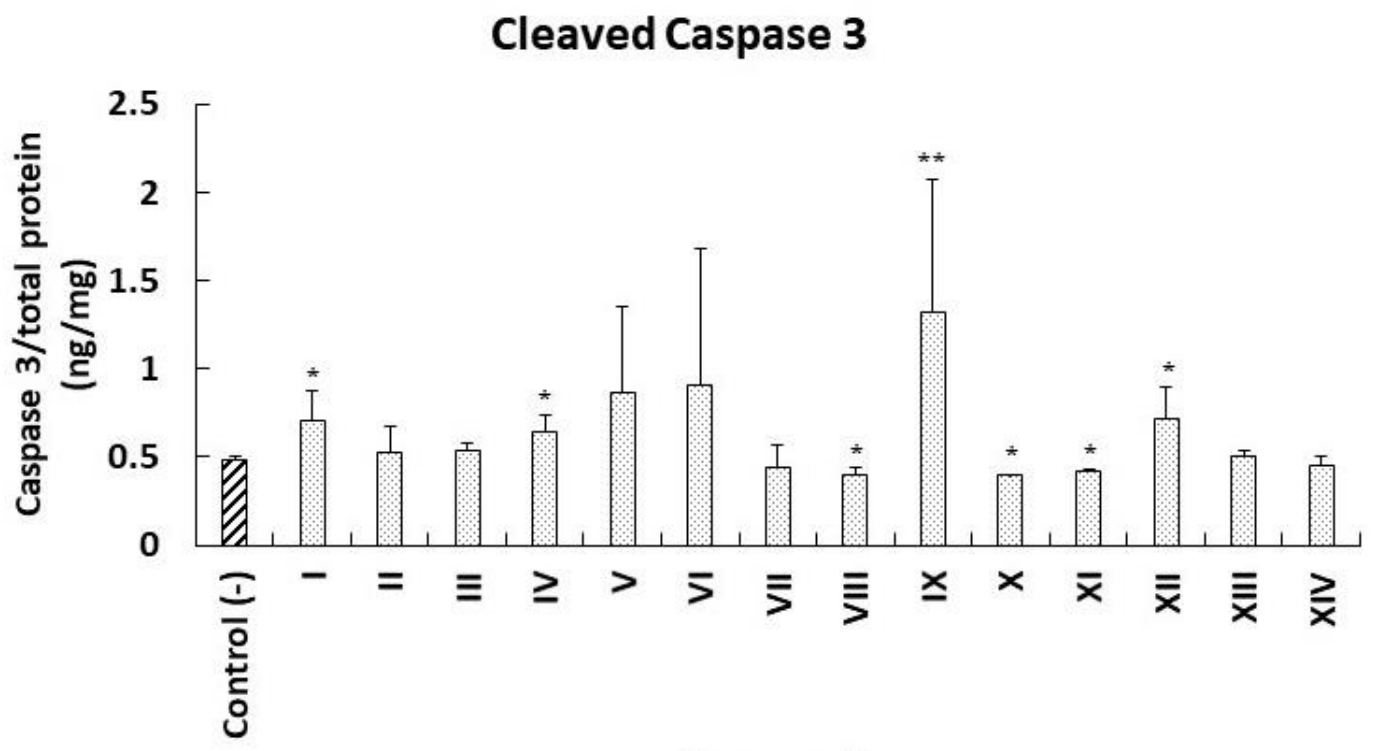

Compounds

Figure 5. PhTAD-substituted dihydropyrrole compounds activate caspase-3 dependent manner apoptosis. Data are expressed as mean \pm S.D. $t$ test. $* * p<0.01$ and $* p<0.05$ vs negative control. $(n=2)$.

\section{Discussion}

Dihydropyrrole compounds are known for their anticancer activities and suppress cell growth in cancer cells. Olszewska et al. demonstrated that fluorinated pyrrole derivatives suppressed proliferation of MCF-7 and lung adenocarcinoma (A549) cells, halted the cell cycle, and shut off cancer cell proliferation. Moreover, these compounds induce caspase-3 activation and promote apoptosis of A549 cells. They have also been observed to markedly restrict the A549 and MCF-7 cancer cells migration levels (Olszewska et al., 2020). Moreover, Ji et al. found that pyrrole analogues showed a significant proliferation inhibitory effect in 10 different cancer cell lines. Furthermore, pyrrolidine stimulates cell cycle arrest and apoptosis mechanisms in both colorectal carcinoma (HCT116) and leukemia cells (HL60) (Ji et al., 2020).

Pyrrole compounds exhibited cytotoxicity in lung adenocarcinoma (PC-9), esophageal carcinoma (Eca-109), and gastric cancer (SGC-7901) cells. The compounds increased the Bax/ Bcl2 ratio and induced apoptosis via caspase-3 activation (Zhu et al., 2017). Pyrrolederived compounds reduce cell viability and have a promising effect. In addition, the compounds induced apoptosis as a possible mechanism for antiproliferative effect (Badolato et al.,2017). Furthermore, Bavadi et al. indicated that the pyrrole compounds showed inhibitory activity and induced apoptosis against leukemia (HL-60), MCF-7, and human acute T lymphoblastic leukemia (MOLT-4) cell lines (Bavadi et al., 2017).

Moreover, compounds with pyrrole structure displayed strong cytotoxic activities in cancer cells in vitro rhabdomyosarcoma (RD), leiomyosarcoma (SK-LMS-1), gastrointestinal osteosarcoma (U-2 OS), Ewing's sarcoma (A-673) and stromal tumor (GIST-T1). These compounds led to both restriction of tubulin polymerization and the induction of a strong G2/M cell cycle arrest (Boichuk et al.,2016). Pyrrole conjugates are cytotoxic to different 
types of cancer cells by promoting DNA damage in endothelial cells, arresting the cell cycle in the G2/M phase, activating apoptotic cell death mechanisms, and inducing vascular endothelial growth factor receptor 2 (VEGFR-2) (Chang et al., 2019).

Some studies have shown that pyrrole derivatives have been synthesized as inhibitors of various protein kinases including EGFR and VEGFR. These compounds induce apoptosis in colorectal cancer cells. Thus, these compounds could be used as inhibitors of EGFR and VEGFR, which may promote the realization of their pro-apoptotic and anti-cancer activities (Kuznietsova et al., 2020). In addition, another study found that pyrrole derivatives JG-03-14 showed reported anti-proliferative activity in MCF-7/caspase-3 cells and the MCF-7/ADR (multidrug-resistant) cell line. It has been demonstrated that this compound stimulates autophagic cell death and is active in cancer cells expressing multi-drug resistance proteins (Arthur et al., 2007). Furthermore, Proto et al. showed that the activity of pyrrole compounds potentiated the inhibitory effect of Nutlin 3, induced apoptosis and significantly impaired melanoma cell lines. It also reduced the p53-MDM2 interaction and induced p53-HSP90 complex formation (Proto et al., 2020).

In addition, pyrrole compounds have very good inhibitory activity against platelet-derived growth factor (PDGFRa), fibroblast growth factor receptor (FGFR-1), LYN, c-KIT, and VEGFR-1/2/3 kinases. Qin et al. demonstrated that the compounds markedly decreased phosphorylated AKT and ERK, strongly inhibited human liver cancer (HepG2), human colorectal adenocarcinoma (HT-29), and human stomach adenocarcinoma (MKN74) cells and encouraged apoptosis (Qin et al., 2020). Synthesized pyrrole-derived compounds were similarly found to be cytotoxic to colon carcinoma cells (HCT116) (Tikhomirov et al., 2020). Zhang et al. indicate that pyrrole-imidazole polyamides prevented proliferation of A549 and SGC-7901 cancer cells; they also suppressed the migration of cancer cells (Zhang et al., 2020).

In this context, the aim of the current research was to investigate how PhTAD-substituted dihydropyrrole compounds affect the expression of apoptotic cell death proteins in the MCF-7 cells. Breast cancer, which is a heterogeneous disease, is categorized into three main subtypes in accordance with the presence or absence of the molecular receptor profile. The first subtype, which is observed in $70 \%$ of patients, is ER and/or PR receptors positive but HER2 receptor negative. At present 92 different cell lines are used in breast cancer studies. However, the MCF7 cell line is the most commonly used since it is positive for ER and PR, while negative for HER2 (Dai et al., 2017). Since this receptor profile is most frequently observed in patients, MCF 7 cells were chosen for this study. In our previous studies, two different cytotoxic activity tests were used to evaluate 14 different compounds on MCF-7 and MCF-12A cells. In the MTT and RTCA assays, the compounds were determined to have very high cytotoxic activity. The $\mathrm{IC}_{50}$ value for the MTT assay of the compounds was between 5 and $54 \mu \mathrm{M}$. The $\mathrm{IC}_{50}$ value for the RTCA assay of the compounds was between 1.5 and 44 $\mu \mathrm{M}$. In the MTT assay, CII, CV, CVI, CIX, CX, and CXIV showed particularly high cytotoxic activity. In addition, in the RTCA assay, CI, CII, CIII, CIV, CXIII and CXIV showed high cytotoxic activity. We applied the appropriate doses on MCF-7 according to the $\mathrm{IC}_{50}$ results obtained in our previous studies, as shown as Table 1. After that, the levels of Bax, Bcl2 and cleaved caspase-3 protein were determined. The results revealed that CI, CII, CIII, CV, CVII, CVIII, CXI and CXII increased Bax protein expression in MCF7 cells, while CXIII and CXIV markedly decreased Bax protein expression (Figure 2). In addition, CI, CII, CIII, CVII, CVIII, and CXII upregulated Bcl2 protein expression; conversely, CIV and CXIV downregulated $\mathrm{Bcl} 2$ protein levels (Figure 3 ). The $\mathrm{Bax} / \mathrm{Bcl} 2$ ratio can be used as an indicator of cell death/or life, thus, we calculated this ratio. CIV, and CXIV increased the Bax/Bcl2 
ratio; however, CVIII, and CXIII decreased the Bax/Bcl2 ratio (Figure 4). This ratio did not change with the application of other compounds. Caspase-3 is an executioner caspase. Caspase-3 activation induces the cleavage of many target substrates, such as lamins, tubulin, and PARP, which are crucial for the occurrence of apoptosis. We therefore measured the cleaved form of caspase-3. CI, CIV, CIX, and CXII treatment increased cleaved caspase-3 protein in the MCF-7 cells compared to negative control. In contrast, CVIII, CX, and CXI treatment decreased cleaved caspase- 3 protein in the MCF-7 cells compared to the negative control (Figure 5). The structure of our compounds is very similar to the reference drugs prodigiosin and obatoclax, which are used as BCL2 inhibitors and cause cancer cell death (Mohammed, 2019; Schwartz-Roberts et al., 2013). Moreover, CIV upregulated both the $\mathrm{Bax} / \mathrm{Bcl} 2$ ratio and caspase-3 protein levels. It is possible that these molecules induce an intrinsic apoptotic pathway in MCF 7 cells. Interestingly, CI, CII, CIII, CV, CIX, and CXII decreased the $\mathrm{Bax} / \mathrm{Bcl} 2$ ratio, while increasing caspase- 3 levels. These alterations may be modulated by either activation of the extrinsic apoptotic pathway or inhibiton of $\mathrm{Bcl} 2$ protein.

In conclusion, our findings indicate that the effects of PhTAD-substituted dihydropyrrole derivative molecules induced the expression of apoptotic proteins as a potential regulator of cancer cell death. In particular, the CI, CIV CIX, and CXII compounds could be used as a potential molecule for anticancer research. Further research is needed to elucidate the mechanisms of action of these molecules on cancer.

\section{Funding}

This work was supported by Amasya University [grant numbers: FMB-BAP 18-0334].

\section{Conflict of Interest}

All authors declare no conflict of interest.

\section{Acknowledgments}

We would like to thank the Amasya University Central Research Laboratory for allowing us to use all their means during the implementation phase of our work.

\section{Authors' contributions}

BY, SM, MA, AA, MG, and TY designed research, analyzed data, and wrote the article, MG synthesized compounds. SM, MA, and TY performed cell culture and protein isolation. BY, and AA conducted the protein determination and ELISA experiments.

\section{References}

AnvariFar, H., Amirkolaie, A. K., Miandare, H. K., Ouraji, H., Jalali, M. A., Üçüncü, S. İ. (2017). "Apoptosis in fish: environmental factors and programmed cell death". Cell and tissue research, 368(3), 425-439.

Ayar, A., Aksahin, M., Mesci, S., Yazgan, B., Gül, M., Yıldırım, T. (2021). Antioxidant, cytotoxic activity and pharmacokinetic studies by SwissAdme, Molinspiration, Osiris and DFT of PhTAD-substituted dihydropyrrole derivatives. Current Computer-aided Drug Design. DOI: 10.2174/1573409917666210223105722. 
Arthur, C. R., Gupton, J. T., Kellogg, G. E., Yeudall, W. A., Cabot, M. C., Newsham, I. F., Gewirtz, D. A. (2007). "Autophagic cell death, polyploidy and senescence induced in breast tumor cells by the substituted pyrrole JG-03-14, a novel microtubule poison". Biochemical pharmacology, 74(7), 981-991.

Ashkenazi, A. (2015). "Targeting the extrinsic apoptotic pathway in cancer: lessons learned and future directions". J Clin Invest, 125(2), 487-489.

Azimian, H., Dayyani, M., Toossi, M. T. B., Mahmoudi, M. (2018).” Bax/Bcl-2 expression ratio in prediction of response to breast cancer radiotherapy". Iranian journal of basic medical sciences, 21(3), 325.

Badolato, M., Carullo, G., Armentano, B., Panza, S., Malivindi, R., Aiello, F. (2017). "Synthesis and anti-proliferative activity of a small library of 7-substituted 5H-pyrrole [1, 2a][3, 1] benzoxazin-5-one derivatives". Bioorganic \& medicinal chemistry letters, 27(14), 3092-3095.

Bavadi, M., Niknam, K., Shahraki, O. (2017). "Novel pyrrole derivatives bearing sulfonamide groups: Synthesis in vitro cytotoxicity evaluation, molecular docking and DFT study". Journal of Molecular Structure, 1146, 242-253.

Belkacemi, L. (2018). "Exploiting the Extrinsic and the Intrinsic Apoptotic Pathways for Cancer Therapeutics". J Cancer Cure. 1(1), 1004.

Boichuk, S., Galembikova, A., Zykova, S., Ramazanov, B., Khusnutdinov, R., Dunaev, P., Lombardi, V. (2016). "Ethyl-2-amino-pyrrole-3-carboxylates are novel potent anticancer agents that affect tubulin polymerization, induce G2/M cell-cycle arrest, and effectively inhibit soft tissue cancer cell growth in vitro". Anti-Cancer Drugs, 27(7), 620-634.

Bray, F., Ferlay, J., Soerjomataram, I., Siegel, R. L., Torre, L. A., Jemal, A. (2018). "Global Cancer Statistics 2018: GLOBOCAN Estimates of Incidence and Mortality Worldwide for 36 Cancers in 185 Countries". CA: A Cancer Journal for Clinicians.

Brentnall, M., Rodriguez-Menocal, L., De Guevara, R. L., Cepero, E., Boise, L. H. (2013). "Caspase-9, caspase-3 and caspase-7 have distinct roles during intrinsic apoptosis". BMC cell biology, 14(1), 32.

Brown, J. M. Attardi, L. D. (2005). "The role of apoptosis in cancer development and treatment response". Nat Rev Cancer. 5(3):231-237.

Chang, S. M., Jain, V., Chen, T. L., Patel, A. S., Pidugu, H. B., Lin, Y. W., Lee, T. C. (2019). "Design and synthesis of 1, 2-bis (hydroxymethyl) pyrrolo [2, 1-a] phthalazine hybrids as potent anticancer agents that inhibit angiogenesis and induce DNA interstrand crosslinks". Journal of medicinal chemistry, 62(5), 2404-2418.

Dai, X., Cheng, H., Bai, Z., \& Li, J. (2017). Breast cancer cell line classification and its relevance with breast tumor subtyping. Journal of Cancer, 8(16), 3131.

Elena-Real, C. A., Díaz-Quintana, A., González-Arzola, K., Velázquez-Campoy, A., Orzáez, M., López-Rivas, A., Díaz-Moreno, I. (2018). "Cytochrome c speeds up caspase cascade activation by blocking 14-3-3e-dependent Apaf-1 inhibition”. Cell death \& disease, 9(3), 112 . 
Elmore, S. (2007). "Apoptosis: a review of programmed cell death". Toxicologic pathology, 35(4), 495-516.

Fuchs, Y., Steller, H. (2011). "Programmed cell death in animal development and disease". Cell, 147(4), 742-758.

Fulda, S. (2013). "How to target apoptosis signaling pathways for the treatment of pediatric cancers". Front Oncol, 3, 22.

Futin, K. M. (2004). “Apoptosis pathways in cancer and cancer therapy". Cancer Immunol Immunother, 53(3), 153-159.

Galluzzi, L., Vitale, I., Aaronson, S. A., Abrams, J. M., Adam, D., Agostinis, P., Annicchiarico-Petruzzelli, M. (2018). "Molecular mechanisms of cell death: recommendations of the Nomenclature Committee on Cell Death 2018". Cell Death \& Differentiation, 25(3), 486-541.

Garbaccio, R. M., Fraley, M. E., Tasber, E. S., Olson, C. M., Hoffman, W. F., Arrington, K. L., Hartman, G. D. (2006). "Kinesin spindle protein (KSP) inhibitors. Part 3: Synthesis and evaluation of phenolic 2, 4-diaryl-2, 5-dihydropyrroles with reduced hERG binding and employment of a phosphate prodrug strategy for aqueous solubility". Bioorganic \& medicinal chemistry letters, 16(7), 1780-1783.

Green, D. R., Llambi, F. (2015). “Cell Death Signaling”. Cold Spring Harbor perspectives in biology, 7(12), a006080.

Gul, M., Elemes, Y., Pelit, E., Dernektsi, E., Georgiou, D., Oikonomou, K., Lis,T., Szafert, S. (2017). Synthesis of PhTAD-substituted dihydropyrrole derivatives via stereospecific C-H amination. Research on Chemical Intermediates, 43(2), 1031-1045.

Howlader, N. N. A. M., Noone, A. M., Krapcho, M., Miller, D., Bishop, K., Kosary, C. L., Cronin, K. A. (2017). "SEER cancer statistics review”, 1975-2014.

Jan, R. Chaudhry, G. E. (2019). "Understanding Apoptosis and Apoptotic Pathways Targeted Cancer Therapeutics". Adv Pharm Bull, 9(2), 205-218.

Ji, J., Sajjad, F., You, Q., Xing, D., Fan, H., Reddy, A. G., Dong, S. (2020). "Synthesis and biological evaluation of substituted pyrrolidines and pyrroles as potential anticancer agents". Archiv der Pharmazie, 353(12), 2000136.

Karna, P. Yang, L. (2009). "Apoptotic signaling pathway and resistance to apoptosis in breast cancer stem cells". In Apoptosis in Carcinogenesis and Chemotherapy, 1-23.

Kominami, K., Nakabayashi, J., Nagai, T., Tsujimura, Y., Chiba, K., Kimura, H., Sakamaki, K. (2012). "The molecular mechanism of apoptosis upon caspase-8 activation: Quantitative experimental validation of a mathematical model". Biochimica et Biophysica Acta (BBA)Molecular Cell Research, 1823(10), 1825-1840.

Kondratskyi, A., Kondratska, K., Skryma, R., Prevarskaya, N. (2015). "Ion channels in the regulation of apoptosis". Biochimica et Biophysica Acta (BBA)-Biomembranes, 1848(10), 2532-2546. 
Kuznietsova, H., Dziubenko, N., Byelinska, I., Hurmach, V., Bychko, A., Lynchak, O., Rybalchenko, V. (2020). "Pyrrole derivatives as potential anti-cancer therapeutics: synthesis, mechanisms of action, safety". Journal of drug targeting, 28(5), 547-563.

Ma, X., \& Yu, H. (2006). "Global burden of cancer". The Yale journal of biology and medicine, 79(3-4), 85-94.

Mohammed, M. R. (2019). Design, synthesis, and cytotoxicity screening of 5-aryl-3-(2(pyrrolyl) thiophenyl)-1, 2, 4-oxadiazoles as potential antitumor molecules on breast cancer MCF-7 cells. Bioorganic chemistry, 86, 609-623.

Nikoletopoulou, V., Markaki, M., Palikaras, K., Tavernarakis, N. (2013). "Crosstalk between apoptosis, necrosis and autophagy". Biochimica et Biophysica Acta (BBA)-Molecular Cell Research, 1833(12), 3448-3459.

Olszewska, P., Cal, D., Zagórski, P., Mikiciuk-Olasik, E. (2020). “A novel trifluoromethyl 2phosphonopyrrole analogue inhibits human cancer cell migration and growth by cell cycle arrest at G1 phase and apoptosis”. European journal of pharmacology, 871, 172943.

Opferman, J. T. (2008). “Apoptosis in the development of the immune system”. Cell Death \& Differentiation, 15(2), 234-242.

Proto, M. C., Fiore, D., Forte, G., Cuozzo, P., Ramunno, A., Fattorusso, C., Franceschelli, S. (2020). "Tetra-substituted pyrrole derivatives act as potent activators of p53 in melanoma cells". Investigational new drugs, 38(3), 634-649.

Qin, M., Tian, Y., Han, X., Cao, Q., Zheng, S., Liu, C., Hou, Y. (2020). "Structural modifications of indolinones bearing a pyrrole moiety and discovery of a multi-kinase inhibitor with potent antitumor activity". Bioorganic \& medicinal chemistry, 28(11), 115486.

Schwartz-Roberts, J. L., Shajahan, A. N., Cook, K. L., Wärri, A., Abu-Asab, M., \& Clarke, R. (2013). GX15-070 (Obatoclax) Induces Apoptosis and Inhibits Cathepsin D-and L-Mediated Autophagosomal Lysis in Antiestrogen-Resistant Breast Cancer Cells. Molecular cancer therapeutics, 12(4), 448-459.

Sebastian, J. (2017). "Dihydropyrazole and dihydropyrrole structures-based design of Kif15 inhibitors as novel therapeutic agents for cancer". Computational biology and chemistry, 68, 164-174.

Siddiqui, W. A., Ahad, A., Ahsan, H. (2015). "The mystery of BCL2 family: Bcl-2 proteins and apoptosis: an update". Archives of toxicology, 89(3), 289-317.

Tarnavsky, S. S., Dubinina, G. G., Golovach, S. M., Yarmoluk, S. M. (2003). "Antitumor activity among derivatives of the 3-chloro-4-(3-hydroxyanilino) -2,5-dihydropyrrole-2,5dione". Biopolymers and Cell, 19(6), 548-552.

Tikhomirov, A. S., Litvinova, V. A., Andreeva, D. V., Tsvetkov, V. B., Dezhenkova, L. G., Volodina, Y. L., Shchekotikhin, A. E. (2020). "Amides of pyrrole-and thiophene-fused anthraquinone derivatives: A role of the heterocyclic core in antitumor properties". European Journal of Medicinal Chemistry, 199, 112294. 
Wang, C., Youle, R. J. (2009). "The role of mitochondria in apoptosis". Annual review of genetics, 43, 95-118.

Wang, D., Li, L., Feng, H., Sun, H., Almeida-Veloso, F., Charavin, M., Désaubry, L. (2018). "Catalyst-free three-component synthesis of highly functionalized 2, 3dihydropyrroles". Green Chemistry, 20(12), 2775-2780.

Wei, L., Jin, X., Cao, Z. Li, W. (2016). "Evodiamine Induces Extrinsic and Intrinsic Apoptosis of Ovarian Cancer Cells via the Mitogen-Activated Protein kinase/phosphatidylinositol-3-kinase/protein Kinase B Signaling Pathways". Journal of traditional Chinese medicine, 36(3), 353-359.

Wu, Y., Wang, D., Wang, X., Wang, Y., Ren, F., Chang, D., Jia, B. (2011). "Caspase 3 is activated through caspase 8 instead of caspase 9 during H2O2-induced apoptosis in HeLa cells". Cellular physiology and biochemistry, 27(5), 539-546.

Zhang, M., Liang, J., Jiang, S. K., Xu, L., Wu, Y. L., Awadasseid, A., Zhang, W. (2020). "Design, synthesis and anti-cancer activity of pyrrole-imidazole polyamides through targetdownregulation of c-kit gene expression”. European Journal of Medicinal Chemistry, 207, 112704.

Zhang, N., Hartig, H., Dzhagalov, I., Draper, D., He, Y. W. (2005). The role of apoptosis in the development and function of T lymphocytes. Cell research, 15(10), 749-769.

Zhu, T., Shen, S., Lu, Q., Ye, X., Ding, W., Chen, R., Ma, T. (2017). "Design and synthesis of novel N (4)-substituted thiosemicarbazones bearing a pyrrole unit as potential anticancer agents". Oncology letters, 13(6), 4493-4500. 